\title{
Notices and Announcements
}

\section{The COMPsych Software Information Service and PC Archive Renamed as PsycLink}

Due to an infringement of copyright, the Psychology Software Information Service formerly known as COMPsych has recently changed its name to PsycLink, a registered trademark owned by the State University of New York.

The PsycLink service, located at the Plattsburgh State University campus, is a comprehensive WWW site for software information related to psychology instruction, research, and practice. In addition to its other services, PsycLink serves as the official PC archive for software submitted to the joumal Behavior Research Methods, Instruments, \& Computers.

In order to ensure that readers have continued access to the original code, authors who have articles accepted for publication in BRMIC are encouraged to submit a copy of their software for inclusion in the PsycLink PC Archive. Information about how to arrange for software submission can be retrieved from http:// www.plattsburgh.edu/psyclink or by sending e-mail to psyclink@splava.cc.plattsburgh.edu. Readers of this journal are also encouraged to take advantage of the full range of other software information services available from PsycLink.

General questions about the PsycLink Software Information Service should be directed to Peter Hornby, Department of Psychology, Plattsburgh State University, Plattsburgh, NY 12901, or by e-mail to hornbypa@, splava.cc.plattsburgh.edu.

\section{9th Annual Meeting of the Psychonomic Society \\ Dallas, Texas \\ November 19-22, 1998}

The 39th Annual Meeting of the Psychonomic Society will be held in Dallas, Texas, at the Wyndham Anatole Hotel. Registration will begin on Thursday evening, November 19. A poster session will be held on Thursday evening; spoken sessions will begin on the morning of Friday, November 20. Sessions will continue through noon on Sunday, November 22.

Programs and hotel reservation cards will be mailed to members and associates in September. Additional programs will be available at the meeting registration desk for $\$ 10.00$.

For further information, please contact the Secretary-Treasurer of the Society: Roger L. Mellgren, Department of Psychology, Box 19528, University of Texas, Arlington, TX 76019-0528 (phone: 81 7-272-2775; fax: 817-272-2364; e-mail: mellgren@uta.edu). 


\section{Society for Computers in Psychology 28th Annual Meeting}

The 28th annual meeting of the Society for Computers in Psychology (SCiP) will be held at the Wyndham Anatole Hotel in Dallas on Thursday, November 19, 1998, prior to the annual meeting of the Psychonomic Society.

Program highlights include: World-Wide Web Applications (Teaching on the Web, Web Experiments, Design and Use of On-line Information Resources, Tutorial on Creating Web Materials); Computers in Undergraduate Laboratories; Computers in Cognitive Research; Computers in Clinical Psychology; Computers in Teaching Statistics and Research Methods.

Douglas Eamon's Presidential Address will be entitled "Distance Education: Has Technology Become a Threat to the Academy?" The keynote speaker, Tom Landauer, will discuss "How Modern Computation Can Turn Cognitive Psychology Into a Real Science." Two invitational symposia will be held: Head-mounted Eyetracking: A New Technique for Experimental Psychology Theories, and Applications of High-Dimensional Semantic Models. There will also be commercial demonstrations and vendor displays.

For more information, visit the SCiP Web page: http://www.lafayette.edu/allanr/scip.html 